
SENIOR LECTURER IN PSYCHOLOGY IN THE DEPARTMENT OF MANAGEMENT
AND BUSINESS STUDIES-The Secretary, Wolverhampton College of Technology, Wolverhampton, quoting Ref. MB.15/2.

SENIOR LECTURER OF LECTORER (with a degree in pharmacy or pharmacology and a higher degree in pharmacology) in PHARMacolocy-The Registrar, City of Leicester Regional College of Technology, Leicester.

SOIL ScIENTIST and an AGRONOMIST at the Institute of Animal science, Cuba, to carry out research and to advise on the development of large-seale production of grains (principally maize and sorghum) and oil seeds-The First Secretary, Cuban Embassy, 22 Mount Street, London, W.1

STUDENT Or JUNIOR TECHNICIAN IN THE CARDIOLOGY DEPARTMENT, to assist in a study of abnormalities of blood-clotting in heart disease- Th

Tetary, st. Mary s Hospital Medical school, Padangton, London, W.2. TEOHNICIAN (preferably female, with some experience in microscopy and The Clerk to the Governors, St. Bartholomew's Hospital, London, E.C.1 quoting Ref. No. ASC/97 and Project No. 842.

ZoologIsTs (M.Sc. or Ph.D. with research experience, and preferably some knowledge of histology and histochemistry) to participate in experimental multidisciplinary programmes of basic research in the field of food additive toxicology-The Director, British Industrial Biological Research Association, Woodmansterne Road, Carshalton, Surrey.

\section{REPORTS and other PUBLICATIONS}

(not included in the monthly Books Supplement)

\section{Great Britain and Ireland}

Philosophical Transactions of the Royal Society of London. Series A Mathematical and Physical Sciences. No. 1100, Vol. 259 (21 April, 1966): The Motion of Slow Positive Ions in Gases. 1: Critical Review, By P. G. Davies, J. Dutton, F. Llewellyn-Jones and E. M. Williams. 2: Mobilities of Potassium and Nitrogen. Ions in Nitrogen. By P. G. Davies, F. Dutton and F. Llewellyn-Jones. 3: Mobilities of Ions in Argon. By P. G. Davies,
J. Dutton, L. F. Llewellyn-Jones and J. A. Rees. 4: Drift and Diffusion of Ions on Hydrogen. By J. Dutton, F. Llewellyn-Jones, W. D. Rees and E. M. Williams. Pp. 299-354. 218.; 3.15 dollars. No. 1101, Vol, 259 (21 April, 1966): A Theoretical study of Flame Properties as a Function of the CharacPp. 355-389. 138. 6d.; 2 dollars. (London: The Royal Society, 1966.) [224. Pp. 355-389. 138. 6d.; 2 dollars. (London: The Royal Society, 1966.) Chamisso. By R. M. Sawicki. (Discovery Reports, Vol. 33.) Pp. 335-384, phamisso. By R. M. Sawicki. (Discovery Reports, Vol. 33.) Pp. 335-384,
plates 22-26. (London: Cambridge University Press, 1966). 408. net. [224 and Harold Lind. Pp. 24. (London: Fabian Society, 1966.) 3s. [224

\section{Other Countries}

Records of the Dominion Museum, Wellington. Vol. 5, No. 13 (6 September 1905): A New Species of Retropinna from Lake Omapere, North Auckland. By R. M. McDowall. Pp. 89-91. Vol, 5, No. 14 (27 August, 1965): Itinerary of Thomas Kirk's Botanical Expeditions. By B. G. Hamlin. Pp. 93-100. Vol. 5, No. 15 (30 Dectmber 1965): (irasses of the Subantarctic Island of the
New Zealand Region. By V. D. Zotov. Pp. 101-146. Vol. 5, No. 16 (28 New Z Ealand Region. By V. D. Zotov. Pp. 101-146. Vol. 5, No. 16 (28 Dorrinion Museum, Wellington. By J. G. J. Kuiper. Pp. 147-162. Vol. 5, No. 17 (28 January, 1966): The New Zealand Species Previously Known as 166. Vol. 5, No. 18 (28 January, 1966): A New Family of the Rissoacea from 166. Vol. 5, No. 18 (28 January, 1966): A New Family of the Rissoacea from 1965. By R. K. Dell. Pp. 22. (Wellington, Dominion Mustum, 1965 and 1966.) [204

Australia: Commonwealth Sclentific and Industrial Research Organiza-
ion. Annual Report of the Computing Research Section, 1964-65. Pp. 34. (Canberra: Commonwealth Scientific and Industrial Research Organization, 1965.)

$[204$

Government of Bechuanaland: Ministry of Min' s, Commerce and Industry Annual Report of the Geological Survey Department for the year ended 30 cents.

204

Australia: Commonwealth Scientific and Industrial Regearch OrganizaLand Research Series, No. 15: General Report on Lands of the Wabag-Tari Area, Territory of Papua and New Guinea, 1960-61. By R. A. Parry, M. J. Bik, E. A. Fitzpatrick, H. A. Haantjens, J. R. McAlpine, R. Pullen, R. G. bourne: Commonwealth Scientific and Industrial Research Organization 1965 .

Publications of the National Research Ccuncil of Canada 1966-Supplement 1. Pp. ili +55. (Ottawa: National Research Council of Canada, 1966.

New Directions in Human Genetics: a Symposium. Edited by Daniel Bergsma and James German. (Birth Defects Original Article Series, Vol. 1,
No. 2.) Pp. 84. (New York, N.Y.: The National Foundation-March of Do. 2.) Pp. 84. (New York, N.Y.: The National Foundation-March of World Health Organization. Monograph Series, No. 23: Laboratory Pp. 178. (Geneva: World Health Organization; London: H.M. Stationery Office, 1966.) 13 Sw. francs; $268.8 d$. $; 5.25$ dollars. India: Council of Sclentific and Industrial Research. Report of the Director of the Central Fuel Research Institute for the year 1962-63. Pp. vi +128. (Jealgora, Dhanbad, Bihar: Central Fuel Research Institute.) [204
Institut Royal Météorologique de Belgique. Bulletin Mensuel. Observations Ionosphériques, Février 1966. Pp. 26. (Ucule-Bruxelles: Institut Royal Météorologique de Belgique, 1966.)

United States Department of the Interior: Geological Survey. Bulletin 1194-I: Mesozcic (?) Rocks in the Baboquivari Mountains, Papago Indian Reservation, Arizona. By L. A. Heindl and C. L. Fair. Pp. iit + 12. 10 cents. Bulletin 1199-H: Bauxite in Areas Adjacent to and Between the Andersonville Districts, Georgia. By Alfred D. Zapp and Lorin D. Clark. Pp. iii + 10+plate 1. Bulletin 1202-A: Geology of the Kayenta and Chilchinbito Quadrangles, Navajo County, Arizona. By E. C. Beaumont and G. H. Dixon. Pp. iv + 28+ plates 1-3. Bulletin 1121 A: Rockfalls and Avalanches from and Robert $K$. Fahnestock. Pp. ili $+30,20$ cents. Water-Supply Paper
Chang, D. B. Simons and E. V. Richardson. Pp. $v+23.20$ cents. Water Supply Paper 1550: Geology of Damsites on Flathead River, Mouth of Flathead Lake, Lake and Sanders Counties, Montana. By Kenneth S. Soward. Pp. vi $+91+$ plates 1-4. Water-Supply Paper 1762: Water in Georgia. By
J. T. Callahan, L. E. Newcomb and J. W. Geurin. Pp. +88 . 45 cents. Professional Paper 403-H: Hydrology of Guam. By Porter E. Ward, Stuar H. Hoffard and Dan A. Davis. Pp. iv $+28+$ plate 1. Professional Paper 422-F: Desiment Yield of the Castaic Watershed, West Los Angeles County California-a Quantitative Geomorphic Approach. By Lawrence K. Lustig.
Pp. iv $+23+$ plates 1 and 2 . 65 cents. (Washington, D.C.: Government Pp. iv $+23+$ plates 1 and 2 . 65 cents. (Washington, D.C.: Government Printing Office, 1965.) Divisjon of Sea Fisheries Investigational Reports. No. 54: Distribution of Inorganic Phosphate and Dissolved Oxygen in the South Wist lndian Ocean. By S. A. Mostert. Pp. 23. No. 55: Hydrology of the South West Indian Ocean. By . . Orren. Pp. 35. No. 56: Movements of the South African Town: Department of Commerce and Industries, Division of Sea Fisheries, Tanzania: Department of Geological Survey. Geologjeal Mups. [204 Tanzania: Department of Geological Survey. Geologjeal Mups. Quarte Quarter Degree Sheet 227: Luika. (Dodoma, Tanzania: Department of

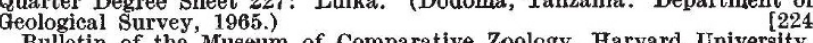
Bulletin of the Museum of Comparative Zoology, Farvard University.
Vol. 133. No. 8 (January 20, 1966): The Relationships of Four Smali Vol. 133, No. 8 (January 20, 1966): The Relationships of Four Smal Pp. 369-399. Vol. 133, No. 9 (January 20, 1966): Two New Fishes of the Myetophid Genus Pp. 401-424. Vol. 133, No. 10 (March 16, 1966): The Ameiva (Lacertilia, Teiidae) of Hispaniola. 2: Geographic Variation in Ameiva chrysolaema Cope. By Albert Schwartz and Ronald F. Klinikowski. Pp. 425-487. (Cam-
bridge, Mass.: Museum of Comparative Zoology at Harvard University [224
Museum of Comparative Zoology at Harvard University. Breviora.
No. 238 (February 25, 1966): An Evaluation of Jamaican Dromicus (SerNo. 238 (February 25, 1966): An Evaluation of Jamaican Dromicus (Serpentes, Colubridae), with the Description of a New Species. By Donald W.
Buden. Pp. 10 . No. 239 (F ebruary 25, 1966): South American Anoles: Anolis bipocratus and Anolis fraseri (Sauris, Iguanidae) Compared. By Arnest E. Williams. Pp. 14. No. 240 (F'ebruary 25, 1966): Gymnothorax galetae, a New Moray Eel from the Atlantic Coast of Panama. By Ira Rubinoff. Pp. 4. No. 241 (February 25, 1966): Avocettinops yanoi, a New Nemichthyid Eel from the Southern Indian Ocean. By Giles W. Mead and Ira Rubinoff. Pp. 6. No. 242 (February 25, 1966): The Supposed "Sponge By William A. S. Sarjeant. Pp. 15. (Cambridge, Mass.: Museum of Comparative Zoology, Harvard University, 1966.)
[224 potulae Naturae of the Academy of Natural Sciences of Philadelphia. No. 373 (February 5,1965 ): The Pennatulid Species, Graphularia ambigua Atlantic and Gulf Coastal Plain. By Earl A. Shapiro and Robert C. Ramsdell. Pp. 7 (1 plate). No. 374 (February 18, 1965): A New Genus of Symbiotic Cockroach from Southwest Africa (Orthoptera: Blattaria: Oxyhaloinae). By James A. G. Rehn. Pp. 8. No. 375 (May 28, 1965): The Protozoa of the Conestoga Basin. By John Cairns, Jr. Pp. 14. No. 376 (May 28, 1965) Additional Observations on West Indian Birds. By Albert Schwartz and Squirrel Fish, Adioryx poco, of the Family Holocentridae from the Bahama Islands. By Loren P. Woods. Pp. 5. No. 378 (September 29, 1965): A Redescription of Sparisoma atomarium (Pcey), a Valid West lndian
Parrotfish. By John E. Randall. Pp. 9. No. 379 (Oetober 28, 1965): Parrotfish. By John E. Randall. Pp. 9. No. 379 (October 28, 1965):
Starksia y-lineata, a New Clinid Fish from Grand Cayman Island, British
West Indies. By Carter R. Gilbert. Pp. 6. No. 380 (October 28, 1965): West Indies. By Carter R. Gilbert. Pp. 6. No. 880 (October 28, 1965): and James E. Böhlke. Pp. 4. No. 381 (D. cember 7, 1965): A Comparison of the Sensitivity to Certain Chemicals of Adult Zebra Danios Brachydanio rerio (Hamilton-Buchanan) and Zebra Danio Eggs with those of Adult Bluegill Sunflsh Lepomis macrochirus Raf. By John Cairns, Jr., Arthur Scheier and Philadelphia, 1965.) 9. (Phladelphia: Academy of Natural Sciences of
Cimbebasia. No. 15: Results of the Percy FitzPatrick InstituteWindhoek State Museum Joint Ornithological Expeditions. 3: Roport on the Birds of the Okavango Valley, By J. M. Winterbottom. Pp. 78 .
(Windhoek, S.W.A.: Staatsmuseum, 1966.)
[224 (Wuomen, Geodeettisen Laitoksen Julkisisuja. Veröfentlichungen des Finnischen Geodatischen Institutes, No. 61 : The Second Levelling of Geodeettisen Laitoksen, 1966.)

Canada: Department of Mines and Technical Surveys. Geclogical Survey of Canada. Bulletin 131: The Permian Ammoneids of Arctio Canada. plates. 2 dollars. Bulletin 135: Type Lithostrotionid Corals from the Mississippian of Western Canada. By $\mathrm{E}$. W. Bamber. Pp. $28+4$ plates. 1.50 dollars. Paper 65-13: Geology of the Brunswick No. 6, and No. 12 Mining Area, Gloucester County, New Brunswick. By C. H. Stockwell and Baffin Island, District of Franklin. By Kate Kranck. Pp. 60.75 cents. Paper 66-12: Unexplored Uranium and Thorium Resources of Canada. By S. M. Roscoe. Pp. 11. 35 cents. (Ottawa: Queen's Printer, 1965 and 1966.)
University of Sydney: School of Agriculture. Report No. 7: Increased Winter and Drought Forage for Tableland Livestook. By F. C. Crofts.
Pp. 43 (12 plates). (Sydney: The University, 1966.)
[224

\footnotetext{
Editorial and Publishing Offices of "NATURE"

MACMILLAN (JOURNALS) LIMITED

4 LITTLE ESSEX STREET, LONDON, W.C.2.

Telephone Number: Temple Bar 6633. Telegrams: Phusis London W.C.2.

Annual subscription: Inland £14, Overseas £13 I5s., payable

in advance, postage paid to any part of the world.

Advertisements only should be addressed to

T. G. Scott \& Son, Ltd., I Clement's Inn, London, W.C.2. Telephone Number: Holborn 4743

Registered as a newspaper at the General Post Office

Copyright (C) Macmillan (Journals) Limited, June 25. 1966
} 